\title{
Quality of Sediment Discharging From the Barton Springs System, Austin, Texas, 2000-2002
}

Four spring outlets of the Barton Springs system provide the only known habitat for the Barton Springs salamander (Eurycea sosorum), a federally listed endangered species. After heavy rainfall, sediment is flushed through the Barton Springs segment of the Edwards aquifer and springflow often becomes turbid (cloudy). Sediment in urban areas often has high concentrations of hydrophobic contaminants, such as DDT, polycyclic aromatic hydrocarbons (PAHs), and lead. In response to concerns that sediment discharging from the Barton Springs outlets could contain contaminants at levels that pose a threat to the health of the salamander or its prey, the U.S. Geological Survey (USGS), in cooperation with the U.S. Fish and Wildlife Service, collected samples of suspended sediment discharging from each of the four spring outlets after two rainstorms and analyzed them for a suite of hydrophobic contaminants.

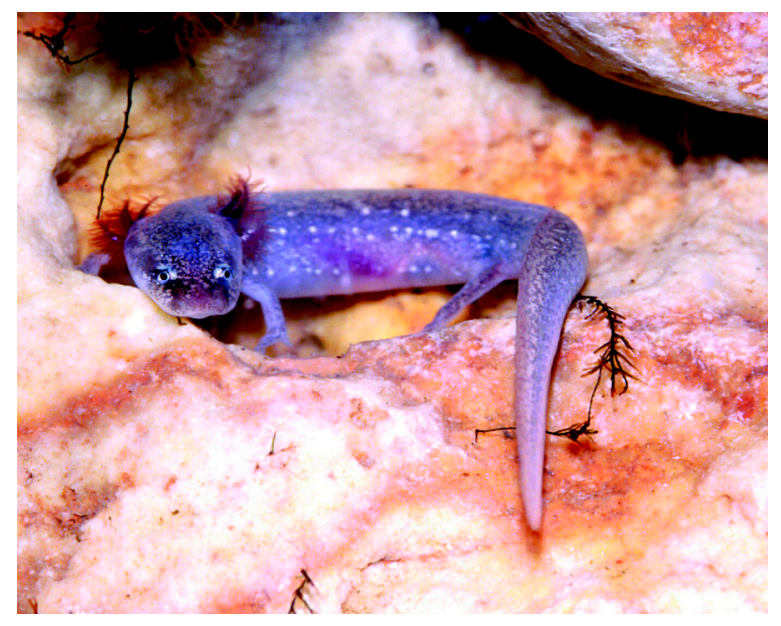

\section{Key Findings}

Concentrations of DDE and PAHs are lower in suspended sediments discharging from the springs than in suspended sediments in nearby urban creeks.

Concentrations of PAHs in suspended sediments discharging from the springs are low compared to sediment-quality guidelines for bed sediments.

Only one organochlorine compound, DDE, was detected

The Barton Springs salamander, a com-
pletely aquatic species, lives in the four spring outlets of Barton Springs. Note the external gills. The salaman2.5 inches long. (Photograph courtesy of Lisa O'Donnell, City of Austin.) in suspended sediments discharging from the springs, although other organochlorine compounds were detected frequently in suspended sediments from nearby urban creeks.

Concentrations of trace elements (metals) in suspended sediments discharging from the springs, which were elevated relative to concentrations in suspended sediments in urban creeks and to sediment-quality guidelines, are largely related to the natural geochemistry of the sediments. 

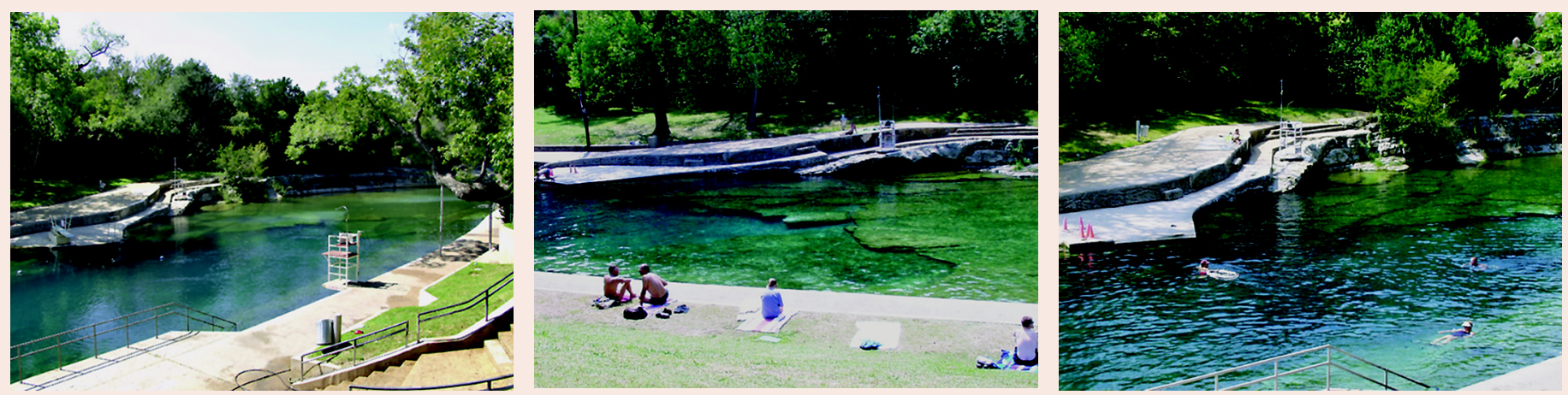

Views of Barton Springs pool. Main Barton Spring discharges from beneath the ledge near the lifeguard stand. (Photographs courtesy of David Johns, City of Austin.)

The Barton Springs system, the fourth largest in Texas, has four main spring outlets: Upper Barton Spring, Eliza Spring, Old Mill Spring (also known as Sunken Garden), and Main Barton Spring (originally named Parthenia Spring). Upper Barton Spring discharges into a small natural pool; discharge from Eliza and Old Mill Springs is retained by structures and then flows into Barton Creek; and Main Spring is retained by a dam, forming the 1,000-foot-long Barton Springs Pool. Main Spring discharges from a series of orifices in the pool bottom, and the volume of water discharged by this outlet is by far the greatest of the four. The average discharge for the whole system is about 53 cubic feet per second $\left(\mathrm{ft}^{3} / \mathrm{s}\right)$, or about 34 million gallons per day, but has been as little as $10 \mathrm{ft}^{3} / \mathrm{s}$ and as great as $166 \mathrm{ft}^{3} / \mathrm{s}$.

The segment of Barton Creek upstream from Barton Springs Pool flows only after rain or during high ground-water levels. It does not flow into Barton Springs Pool but instead is routed around the pool through a bypass. In times of flood, however, it overtops the dam separating it from the pool and Main Barton Spring, delivering water and sediment from the creek into the pool.

Most of the recharge to the aquifer feeding the Barton Springs system infiltrates through fractures and fissures in the beds of five creeks (Slade and others, 1986); recharge from these creeks can take as little as several hours to many days to arrive at the springs (Hauwert, 2001). Water discharging from the four spring outlets usually is clear, with suspended sediment concentrations of a few milligrams per liter or less. After a rain of 1 inch or more, however, spring discharge often becomes turbid, and suspended sediment concentrations can exceed 100 milligrams per liter.

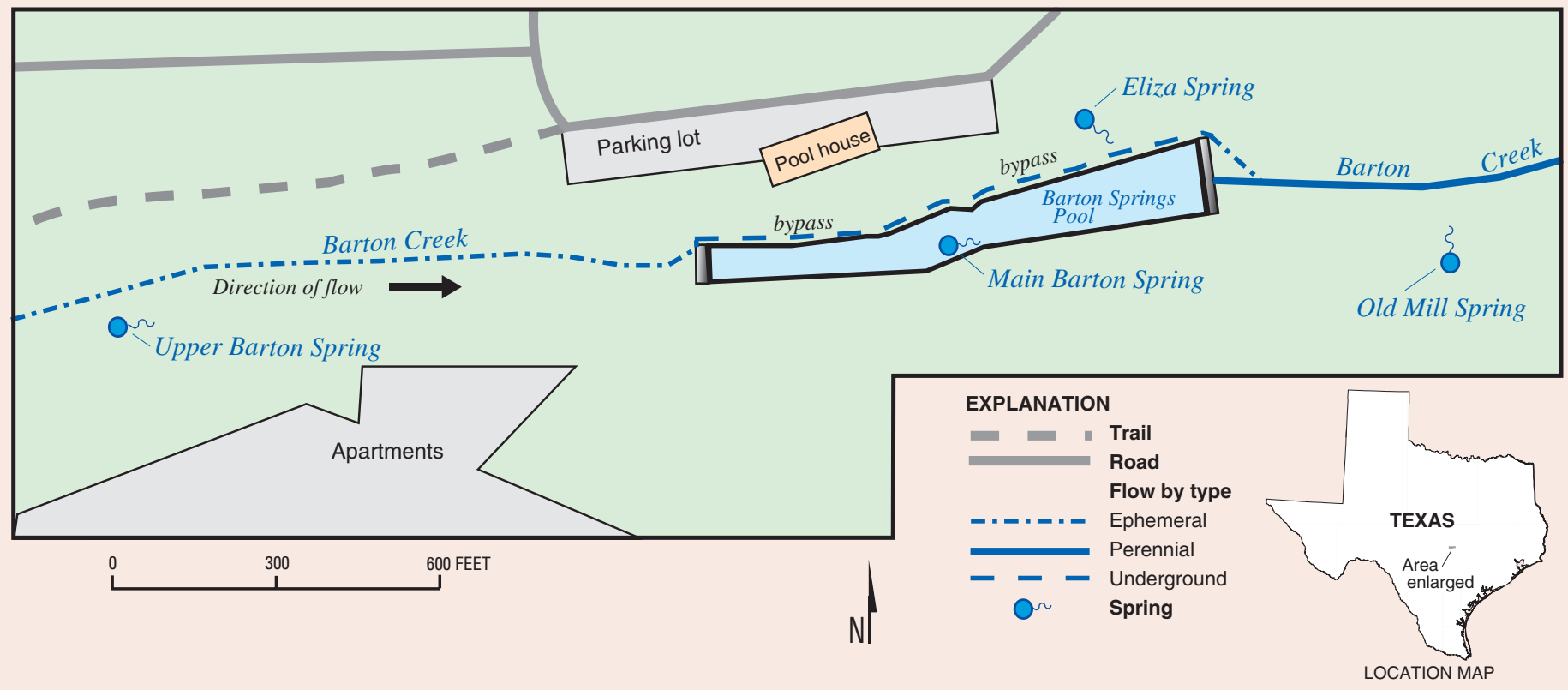

Figure 1. Location of Barton Springs system. Suspended sediment samples were collected from the four spring sites shown; the hydrogeologically connected springs compose the Barton Springs system. Flow in the creek is from left to right. 


\section{How we collect a suspended} sediment sample ...

Suspended sediment is isolated from water by in-line filtration. Tubing is inserted in the spring orifice and pumped through a Teflon filter held in either a stainless steel filter holder (for analysis of organic contaminants) or an acrylic filter holder (for analysis of major elements and metals) until the filter clogs. The filter is removed from the holder, placed in a locking plastic bag, and massaged to remove the sediment. The filter then is replaced in the holder, and more water is filtered. Sampling begins once the spring water is turbid, generally 12 to 24 hours after rainfall, and continues for several hours until the turbidity has peaked and started to decrease. Details on sample collection and processing can be found in Mahler and Van Metre (2003).

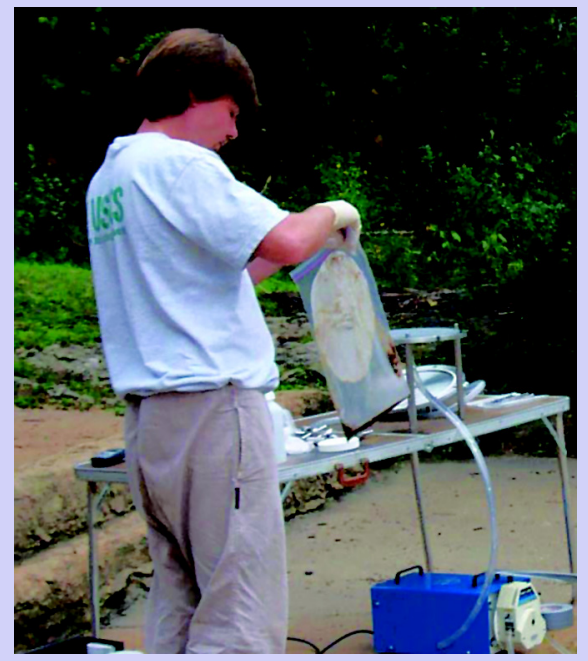

USGS hydrologist Marcus Gary collects suspended sediment at Main Barton Spring. The sediment has been removed from the filter by massaging and has collected in the bottom of the locking plastic bag. The blue peristaltic pump and the stainless steel filter holder are visible in the background.

\section{... and how it's analyzed.}

Samples are analyzed for organochlorine compounds, PAHs, and major and trace elements (metals) at the USGS National Water Quality Laboratory, using the following USGS methods: Organochlorine compounds and PAHs are measured by dual capillary-column gas chromatography with electron capture detection (Foreman and others, 1995; Furlong and others, 1996); major and trace elements are measured by inductively coupled plasma/mass spectrometry (ICP/MS) (Briggs and Meier, 2003), except for mercury, which is measured by cold vapor atomic adsorption spectroscopy (Brown and others, 2003).

\section{Study Results and What They Mean}

During 2000-2002, the USGS collected two suspended sediment samples each from Eliza, Old Mill, and Upper Barton Springs (fig. 1) as part of this study; and collected four suspended sediment samples from Main Barton Spring as part of a cooperative program with the City of Austin. Results for DDE (the only organochlorine detected), selected PAHs, and metals are listed in table 1 (back page). Total PAH was computed as the sum of 13 parent PAHs (MacDonald and others, 2000). Two sedimentquality guidelines developed by MacDonald and others (2000) also are shown: The threshold effect concentration (TEC) is the concentration below which bed sediment is not expected to adversely affect benthic biota, and the probable effect concentration (PEC) is the concentration above which bed sediment is expected to adversely affect benthic biota. The guidelines were developed to evaluate the toxicity of bed sediment, not suspended sediment, but they are a useful guideline for evaluating the relative contamination of suspended sediment.

All samples were collected as suspended sediments except one sample each from Old Mill and Upper Barton Springs, which were collected as bed sediment samples for logistical reasons. Major-element and grain-size data (not shown) indicated that the bed sediment sample from Old Mill most likely represented suspended sediment, but that the bed sediment sample from Upper Barton did not. In the Upper Barton bed sediment sample, concentrations of calcium and magnesium (associated with limestone) were much higher than in suspended sediment samples, concentrations of aluminum, iron, and titanium (associated with clay minerals) and organic carbon were much lower, and the bed sediment sample had a much larger proportion of sand-size grains (almost 50 percent) than the suspended sediment samples. These findings suggest that at Upper Barton, suspended sediment discharging from the spring is sorted by size after discharge, with the larger particles settling next to the spring and the smaller clay particles remaining in suspension and being transported downstream by springflow.

Contaminant concentrations in discharging spring sediments were compared to those in suspended sediments collected by the USGS in stormflow from two creeks in the Barton Springs recharge zone during 2000-2002 as part

\section{Hydrophobic, or "Water Fearing," Contaminants and Their Sources}

Hydrophobic contaminants are those that, because of their chemical composition, tend to adsorb to particles at concentrations of a thousand to a million times greater than their concentrations in water. Hydrophobic contaminants detected at very high concentrations in sediment might not be detected in water. Three groups of hydrophobic contaminants (organochlorine compounds, PAHs, and metals) were analyzed for this study.

\section{Organochlorine Compounds}

The most frequently detected organochlorines in the environment are polychlorinated biphenyls (PCBs) and the insecticides DDT (and its breakdown products DDE and DDD), chlordane, and dieldrin. PCBs were widely used in the 1960s and 1970s in industrial equipment; their manufacture was banned in 1978. DDT was banned in 1972 after the toxicity and persistence of DDT and its breakdown products were widely publicized in Rachel Carson's (1962) book Silent Spring. Chlordane was used to control termites and fire ants until its ban in 1988. Although use of all of these products has been discontinued, they are still detected in suspended sediments in urban creeks and in lake sediments.

\section{Polycyclic Aromatic Hydrocarbons}

PAHs are the largest class of suspected cancer-causing agents (Björseth and Ramdahl, 1985). PAHs are produced by incomplete combustion of petroleum, oil, coal, and wood. They occur naturally in the environment at very low concentrations, but numerous anthropogenic (human-related) sources exist including vehicles, coal and wood fires, and power plant emissions. Recent investigations by the City of Austin indicate that parking lot sealants containing coal tar might be an important source of PAHs in the urban environment (Austin American-Statesman, 2003). Concentrations of PAHs in sediment cores from urban lakes and reservoirs across the Nation increase greatly in more recently deposited sediments compared to older sediments (Van Metre and others, 2000).

\section{Metals}

The metals analyzed for this study are arsenic (actually a metalloid), cadmium, chromium, copper, lead, mercury, nickel, and zinc. Metals occur naturally in all geologic settings at a range of concentrations. Anthropogenic sources such as urban runoff, smelting, and landfills also deliver metals into the environment. In the urban environment, some common sources of metals are rubber tires (zinc), wheel weights (lead), pressure-treated wood (arsenic, chromium, copper), brake pads (copper), and lubricating oil and grease (lead, nickel, zinc). 


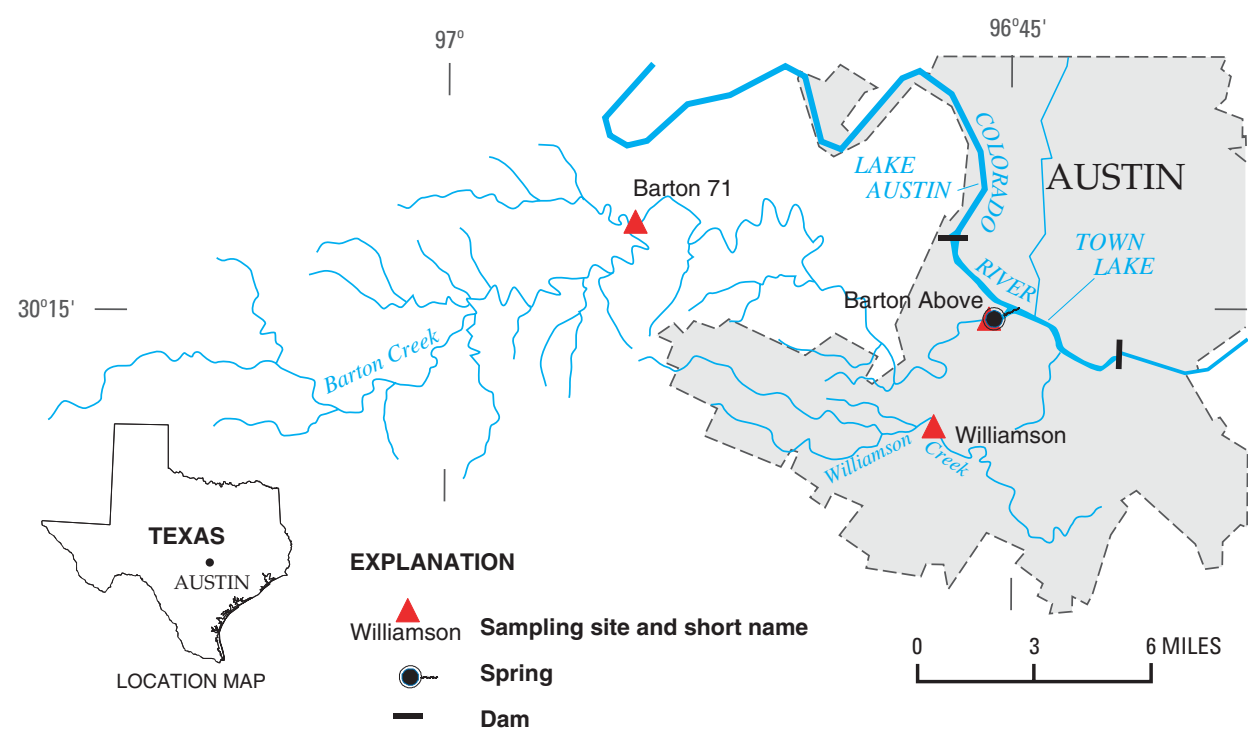

Figure 2. Locations of sampling sites for suspended sediments in surface water.

of a cooperative program with the City of Austin. The creek sample sites are Barton Creek at State Highway 71 (Barton 71), Barton Creek above Barton Springs Pool (Barton Above), and Williamson Creek at Manchaca Road (Williamson) (fig. 2). Barton 71 is in a relatively undeveloped part of the Barton Creek watershed, and Barton Above and Williamson are in more intensely developed (urbanized) parts of the watershed. Flow-weighted composite samples were collected so that concentrations would represent an average for the rainstorm; the sediments were analyzed using methods similar to those described here for discharging spring sediments (Mahler and Van Metre, 2003).

\section{Organochlorine Compounds}

Of the organochlorine compounds analyzed, only DDE was detected in discharging spring sediments. DDE was detected in at least one sample from each spring outlet except Upper Barton (fig. 3; table 1). Concentrations were low and exceeded the TEC in only one sample. In contrast, DDE was detected in every one of the surface-water samples collected during the sampling period and exceeded the TEC for most of the samples collected at the two moreurbanized sites. The occurrence of DDE in discharging spring sediments confirms that surface-water sediment is transported through the aquifer, although the time scale for this transport is unknown-discharging sediment could have infiltrated the aquifer during the sampled event or at an earlier time. The lower DDE concentrations detected in spring suspended sediments suggest that contaminated sediments in recharge water might be diluted by "cleaner" sediments. These cleaner sediments could be coming from other, less-developed watersheds such as Onion Creek or Bear Creek (watersheds feeding the Barton Springs system), from within the aquifer itself, or both. Mineralogic differences between recharging and discharging sediments (higher aluminum,
National Park near Estes Park, Colo. (P.C. Van Metre, U.S. Geological Survey, unpub. data, 1999). In contrast, concentrations of total $\mathrm{PAH}$ at the two more-urbanized sites are 10 to 100 times higher than those in Mills Lake. PAH concentrations at Williamson, in particular, were extremely high, exceeding concentrations for all other samples by as much as five times (fig. 3). In this case, urbanization appears to have increased contamination of surface-water sediments by PAHs.

\section{Metals}

In contrast to the low concentrations of organochlorine compounds and PAHs in suspended sediments discharging from the aquifer, metals concentrations were elevated compared to sediment-quality guidelines (fig. 4). Arsenic, chromium, and nickel exceeded the respective TEC in eight or more of 10 samples, and nickel exceeded the PEC in one sample (table 1). For arsenic, chromium, copper, and nickel, the median concentration in discharging spring sediment exceeded that in the surface-water sediments. However, for lead and zinc, two metals shown to be strongly related to urban land use (Callender and Rice, 2000), median concentrations in suspended creek sediments exceeded those in discharging spring sediments.

Why do discharging spring sediments have higher concentrations of metals than suspended sediments in creeks, if creek sediments are

\section{not detected in spring sediments at laboratory}

PCB Aroclors 1242,1254 , and 1260 were reporting levels. Reporting levels for any individual organochlorine compound in suspended sediment vary depending on the mass of sediment analyzed, with small sample masses usually having higher reporting levels. Reporting levels for this study ranged from 1.0 to 550 micrograms per kilogram $(\mu \mathrm{g} / \mathrm{kg})$; the median reporting level for 11 of the compounds was $7.0 \mu \mathrm{g} / \mathrm{kg}$. Five compounds had higher median reporting levels: chlordane and the three PCB Aroclors $(70 \mu \mathrm{g} / \mathrm{kg})$ and methoxychlor $(24 \mu \mathrm{g} / \mathrm{kg})$.

Organochlorine compounds not detected in discharging spring sediments were detected in some suspended sediment samples from the creeks, in some cases at high concentrations. For example, chlordane was detected in one sample from Barton Above and two from Williamson; concentrations in all three samples exceeded the PEC of $18 \mu \mathrm{g} / \mathrm{kg}$ (Mahler and Van Metre, 2003).

\section{Polycyclic Aromatic Hydrocarbons}

Total PAH concentrations associated with suspended sediments at the two urbanized surface-water sites were markedly different from those at the other sites (fig. 3). Total PAH concentrations at the spring sites and the lightly developed surface-water site (Barton 71) were all below the TECs. To provide a context for the results, concentrations of these samples are similar to those analyzed in a sediment core from Mills Lake, a remote lake in Rocky Mountain

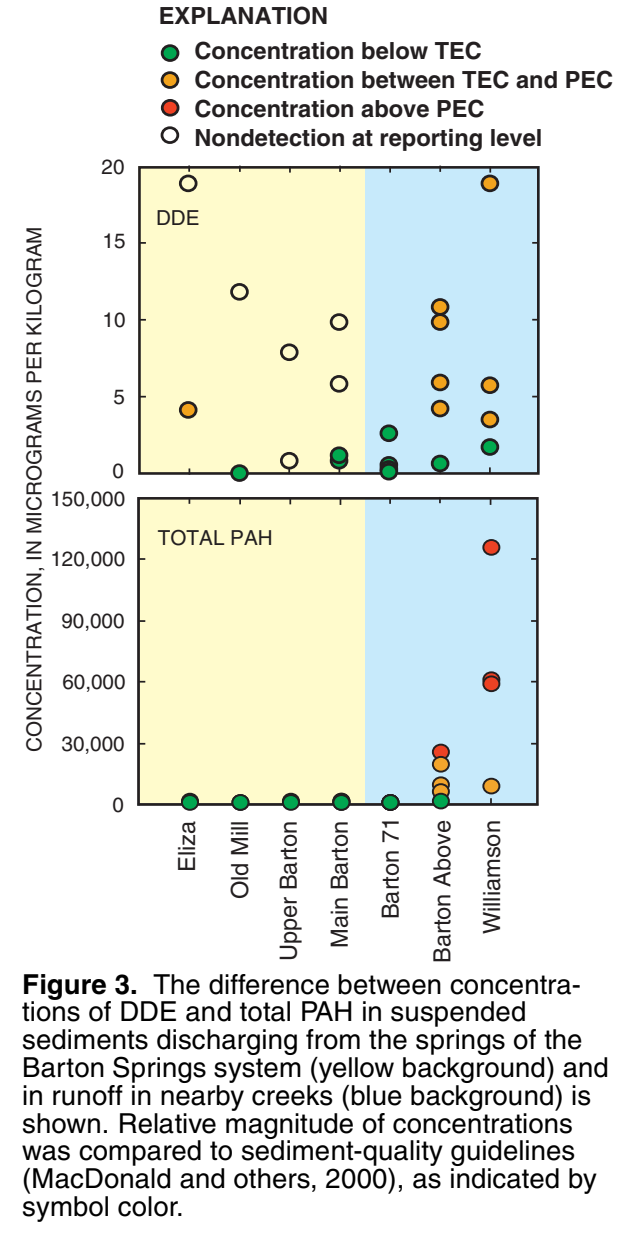

Concentratior

- Concentration above PEC Nondetection at reporting level tions of DDE and total PAH in suspended sediments discharging from the springs of the Barton Springs system (yellow background) and in nearby creeks (blue background) is was compared to sediment-quality guidelines symbol color 
much more contaminated by organochlorine compounds and PAHs? The natural geochemistry of the sediments might be the explanation. Metals occur over a wide range of concentrations in geologic materials, but tend to concentrate in the iron and manganese hydroxides that sometimes coat clay minerals (Hem, 1992). One way to determine if the concentration of a metal in sediment is higher than the naturally occurring background concentration is to compare the metal concentrations of a suite of sediment samples from a similar geologic setting to the iron concentration. If the metal concentration varies proportionately with iron, assumed to have a natural source, the metal also is assumed to have a natural source. If metal concentrations are graphed in relation to iron concentrations, the samples for which the metal concentrations vary proportionately with iron concentration will plot along a straight line. Samples that plot above the straight line have a disproportionately large concentration of the metal in comparison to iron.

All of the metals that were elevated in discharging spring sediments compared to suspended sediments in creeks-arsenic, chromium, copper, and nickel—correlate well with iron concentration (fig. 5), indicating a non-anthropogenic (or natural) source. The few outliers indicate that some samples might have an anthropogenic contribution, for example, one sample for nickel in Upper Barton (May 8, 2001) and one sample for copper in Eliza (November 3, 2000). In general, though, the elevated concentrations of most metals in discharging aquifer sediments seem to be a natural consequence of high iron concentrations rather than pollution.

In contrast, a strong anthropogenic source of lead and zinc is evident for suspended sediments at the two urbanized surface-water sites (fig. 5). Suspended sediments from Barton Above and Williamson plot in a group above the line indicating a proportional variation between iron and these two metals; concentrations are more than three times the background concentrations expected on the basis of iron concentrations for some samples, quantified by the distance between the straight line and the highest plotted points.
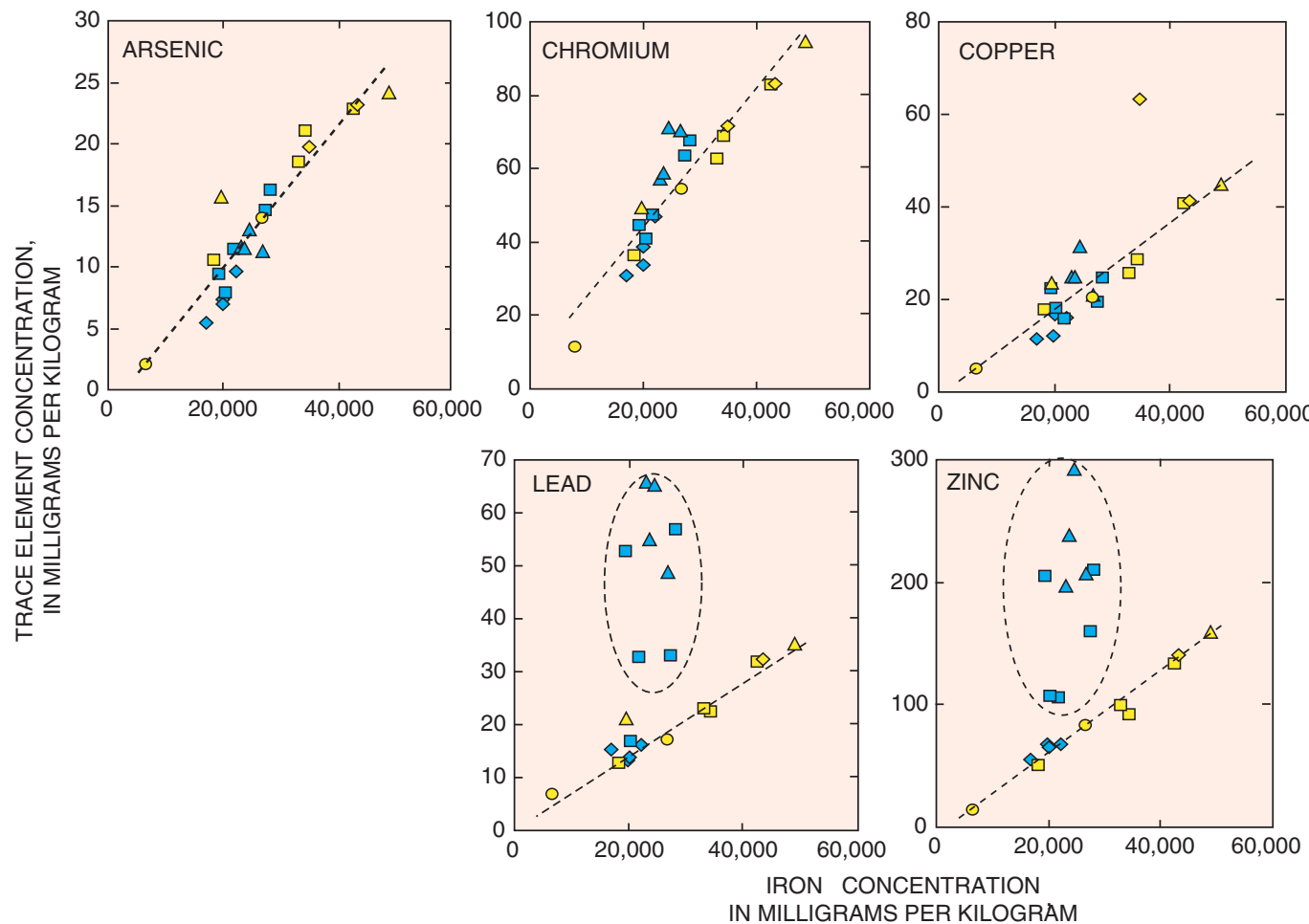

IN MILLIGRAMS PER KILOGRAM

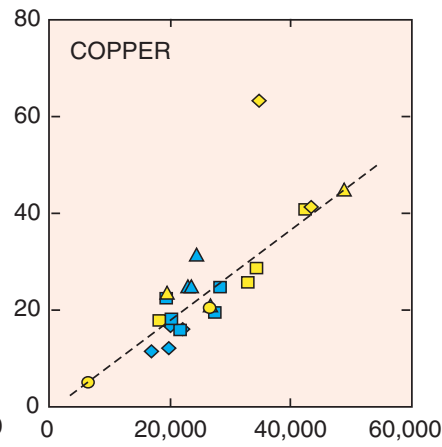

\section{EXPLANATION}

- - - Median concentration for spring or surface-water suspended sediment

- Concentration below TEC

Concentration between TEC and PEC

- Concentration above PEC

Figure 4. Concentrations of selected metals in suspended sediments discharging from springs (yellow background) and in surface streams (blue background) are compared. Only for lead and zinc, two metals with a strong urban source signal (Callender and Rice, 2000), were the median concentrations higher in surface-water sediments than in spring sediments. Relative magnitude of concentrations was compared to sediment-quality guidelines (MacDonald and others, 2000), as indicated by symbol color.

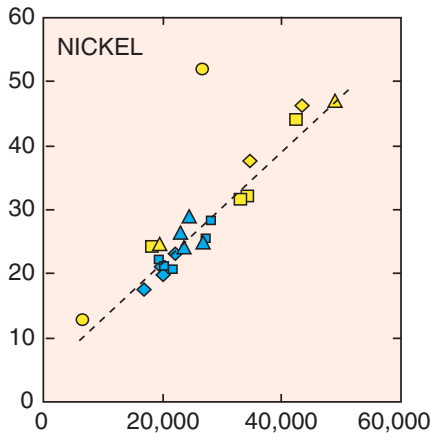

EXPLANATION

Surface-water suspended sediment

$\diamond$ Barton 71

- Barton Above

$\triangle$ Williamson

Spring suspended sediment Main Barton

$\diamond$ Eliza

$\triangle$ Old Mill

Upper Barton

Figure 5. Correlation of concentrations of different metals to concentration of iron in suspended sediments indicates which samples might have an

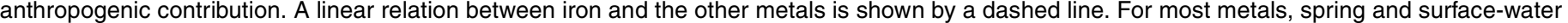

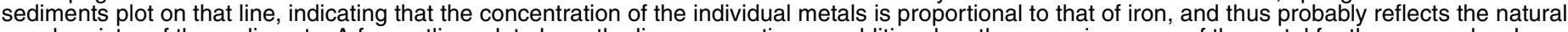

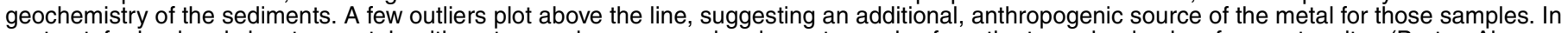

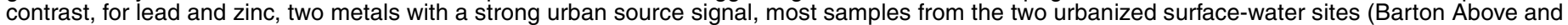

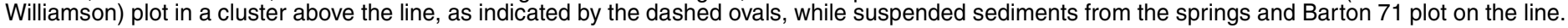


Table 1. Concentrations of organic carbon, DDE, selected PAHs, and metals in suspended sediments discharging from the Barton Springs system

[Concentrations exceeding the TEC shown in blue and one exceeding the PEC shown in red; see text for additional compounds not detected. $\mu \mathrm{g} / \mathrm{kg}$, micrograms per kilogram; mg/kg, milligrams per kilogram; I.S., insufficient sediment for analysis; E, estimated; <, less than; TEC, threshold effect concentration (MacDonald and others, 2000); --, not applicable; PEC, probable effect concentration (MacDonald and others 2000)]

\begin{tabular}{|c|c|c|c|c|c|c|c|c|c|c|c|c|c|c|c|c|c|c|}
\hline Spring & Date & $\begin{array}{c}\text { Organic } \\
\text { carbon } \\
\text { (per- } \\
\text { cent) }\end{array}$ & $\begin{array}{c}\text { DDE } \\
(\mu \mathbf{g} / \mathbf{k g})\end{array}$ & $\begin{array}{c}\text { Total } \\
\text { PAH } \\
(\mu \mathrm{g} / \mathrm{kg})\end{array}$ & $\begin{array}{c}\text { Anthra- } \\
\text { cene } \\
(\mu \mathrm{g} / \mathrm{kg})\end{array}$ & $\begin{array}{c}\text { Fluoran- } \\
\text { thene } \\
(\mu \mathrm{g} / \mathrm{kg})\end{array}$ & $\begin{array}{l}\text { Pyrene } \\
(\mu \mathrm{g} / \mathrm{kg})\end{array}$ & $\begin{array}{c}\text { Benz[a]- } \\
\text { anthra- } \\
\text { cene } \\
(\mu \mathrm{g} / \mathrm{kg})\end{array}$ & $\begin{array}{c}\text { Chry- } \\
\text { sene } \\
(\mu \mathrm{g} / \mathrm{kg})\end{array}$ & $\begin{array}{c}\text { Benzo(a)- } \\
\text { pyrene } \\
(\mu \mathrm{g} / \mathrm{kg})\end{array}$ & $\begin{array}{l}\text { Arsenic } \\
(\mathrm{mg} / \mathrm{kg})\end{array}$ & $\underset{\substack{\text { Cad- } \\
\text { mium } \\
(\mathrm{mg} / \mathrm{kg})}}{ }$ & 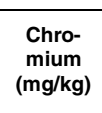 & $\begin{array}{c}\text { Cop- } \\
\text { per } \\
(\mathrm{mg} / \mathrm{kg})\end{array}$ & $\begin{array}{c}\text { Mer- } \\
\text { cury } \\
(\mathrm{mg} / \mathrm{kg})\end{array}$ & $\begin{array}{c}\text { Nickel } \\
(\mathrm{mg} / \mathrm{kg})\end{array}$ & $\begin{array}{l}\text { Lead } \\
(\mathrm{mg} / \mathrm{kg})\end{array}$ & $\underset{(\mathrm{mg} / \mathrm{kg})}{\mathrm{Zinc}}$ \\
\hline \multirow[t]{2}{*}{$\overline{\text { Eliza }}$} & 11-03-00 & I.S. & E4.3 & E769 & E30.3 & E105 & E89.2 & E62.6 & E96.3 & E107 & 19.8 & 0.96 & 71.8 & 63.2 & 0.015 & 37.7 & 34.9 & 138 \\
\hline & $11-16-01$ & 4.73 & $<19$ & E322 & E36.1 & E37.7 & E37.3 & E58.2 & E4.1 & E75.5 & 23.2 & .47 & 83.3 & 41.4 & I.S. & 46.3 & 32.4 & 141 \\
\hline \multirow{2}{*}{ Old Mill } & $05-17-01$ & 2.72 & E. 2 & E102 & $<10$ & 16.9 & 12.9 & 10.3 & 16.5 & 12.5 & 15.7 & .19 & 49.3 & 23.6 & .05 & 24.6 & 21.2 & 67.6 \\
\hline & & I. & $<12$ & E302 & E2 & E & E29.2 & E37.9 & & $\mathrm{E}$ & 2 & 6 & 94.8 & & I.S. & & 353 & 160 \\
\hline \multirow[t]{2}{*}{ Upper Barton } & 05-08-01 & I.S & $<8.0$ & E395 & E18.5 & E53.3 & E46. & E37.3 & E27.0 & E41.0 & 13.9 & .22 & 54.2 & 20 & I.S. & 51.9 & 17.0 & 83.4 \\
\hline & $03-12-02$ & $<.0$ & $<1.0$ & E80 & 3.0 & 13 & 12. & E6.8 & E7.4 & E8. & 2.04 & .07 & 11. & 5.06 & .02 & 12. & 6.64 & \\
\hline \multirow[t]{4}{*}{ Main Barton } & $3-00$ & 2.0 & E1. & E177 & F5 & E23 & E19 & F12 & $\mathrm{F}$ & E & 21 & .7 & 68 & 28 & .0 & 3 & 22 & 91.3 \\
\hline & $05-07-01$ & 1.6 & $<6.0$ & E360 & E21 & E4 & E41.2 & E3 & E25.9 & E. & 18 & .4 & 36 & & .08 & 2 & 12 & 50.4 \\
\hline & $08-27-01$ & I.S & $<10$ & E632 & E20.4 & E98.3 & E81.3 & E53.4 & E59.1 & E85.6 & 18. & .3 & 62.6 & 25 & I.S. & 31.6 & 23.0 & 99.7 \\
\hline & $11-16-01$ & 3.56 & E1.3 & E328 & E16.8 & E41.2 & E36.3 & E33.9 & E19.5 & E48.4 & 22.8 & .58 & 82.8 & 40.8 & .07 & 44.0 & 31.8 & 133 \\
\hline TEC & -- & -- & 3. & 1,610 & 57.2 & 42 & 1 & & 166 & & 9.79 & .9 & 43. & .6 & .1 & 22.7 & 35.8 & 12 \\
\hline PEC & -- & -- & 31.3 & 22,800 & 845 & 2,230 & 1,520 & 1,050 & 1,290 & 1,450 & 33.0 & 4.98 & 111 & 149 & 1.06 & 48.6 & 128 & 459 \\
\hline
\end{tabular}

\section{What Can We Conclude About Sediments Discharging From the Springs and Transported in Urban Creeks?}

Suspended sediments discharging from Eliza, Old Mill, Upper Barton, and Main Barton Springs analyzed for this report show minor effects from the urbanization occurring within their watershed. Only one organochlorine compound, DDE, was detected in spring sediments. PAHs were detected at concentrations similar to those in nonurbanized environments. Concentrations of metals were elevated in many cases relative to the TECs, but the elevated concentrations, with only a few exceptions, are related to the natural geochemistry of the discharging sediment rather than to contamination.

In contrast, concentrations of DDE, PAHs, and lead and zinc were higher in suspended sediments collected at two surface-water sites in the

\section{References Cited}

Austin American-Statesman, 2003, Parking lot contaminant theory explored (by R.K.M. Haurwitz, February 4, 2003): Austin, p. A6.

Björseth, Alf, and Ramdahl, T., eds., 1985, Handbook of polycyclic aromatic hydrocarbons-Emission sources and recent progress in analytical chemistry, v. 2: New York, Marcel Dekker, 432 p.

Briggs, P.H., and Meier, A.L., 2003, The determination of forty-two elements in geological materials by inductively coupled plasma/mass spectrometry for NAWQA: U.S. Geological Survey Open-File Report 02-223-I, $16 \mathrm{p}$.

Brown, Z.A., O’Leary, R.M., Hageman, P.L., and Crock, J.G., 2003, Mercury in water, geologic, and plant materials by continuous flow/cold vapor/ atomic adsorption spectroscopy: U.S. Geological Survey Open-File Report 02-223-M, 11 p.

Callender, Edward, and Rice, K.C., 2000, The urban environmental gradient-Anthropogenic influences on the spatial and temporal distributions of lead and zinc in sediments: Environmental Science and Technology, v. 34 , no. 2 , p. $232-238$.

Carson, Rachel, 1962, Silent spring: Boston, Houghton Mifflin, 386 p.

Foreman, W.T., Connor, B.F., Furlong, E.T., Vaught, D.G., and Merten, L.M., 1995, Methods of analysis by the U.S. Geological Survey National Water Quality Laboratory-Determination of organochlorine pesticides and polychlorinated biphenyls in bottom sediment by dual capillarycolumn gas chromatography with electron-capture detection: U.S. Geological Survey Open-File Report 95-140, 78 p.

Furlong, E.T., Vaught, D.G., Merten, L.M., Foreman, W.T., and Gates, P.M., 1996, Methods of analysis by the U.S. Geological Survey National Water Quality Laboratory-Determination of semivolatile organic compounds in bottom sediment by solvent extraction, gel permeation chromatographic fractionation, and capillary-column gas chromatography/ mass spectrometry: U.S. Geological Survey Open-File Report 95-719, $67 \mathrm{p}$. more-urbanized part of the watershed than they were either in the spring sediments or in suspended sediments collected at a surface-water site in a less-urbanized part of the watershed. Concentrations of hydrophobic contaminants associated with suspended sediments at the urbanized surfacewater sites were in many cases several times higher than sediment-quality guidelines for the health of benthic biota. Although the creeks sampled recharge the aquifer feeding Barton Springs, sediments currently (2002) discharging from the springs are relatively uncontaminated. Possible reasons include dilution of contaminated sediments by cleaner sediments and storage of contaminated recharging sediments in the aquifer. The results of the study described in this report indicate that urbanization of the watershed has not yet resulted in extensive degradation of the quality of sediment discharging from the Barton Springs system.

- B.J. Mahler
Hauwert, N.M., 2001, Research program summary-Groundwater tracing: Barton Springs/Edwards Aquifer Conservation District, accessed June 20, 2003, at URL http://www.bseacd.org/graphics/Groundwater_Tracing_Study_R.pdf

Hem, J.D., 1992, Study and interpretation of the chemical characteristics of natural water (3d ed.): U.S. Geological Survey Water-Supply Paper 2254, $263 \mathrm{p}$.

MacDonald, D.D., Ingersoll, C.G., and Berger, T.A., 2000, Development and evaluation of consensus-based sediment quality guidelines for freshwater ecosystems: Archives of Environmental Contamination and Toxicology, v. 39, p. 20-31.

Mahler, B.J., and Van Metre, P.C., 2003, A simplified approach for monitoring hydrophobic organic contaminants associated with suspended sediment-Methodology and applications: Archives of Environmental Contamination and Toxicology, v. 44, no. 4, p. 288-297.

Slade, R.M., Jr., Dorsey, M.E., and Stewart, S.L., 1986, Hydrology and water quality of the Edwards aquifer associated with Barton Springs in the Austin area, Texas: U.S. Geological Survey Water-Resources Investigations Report 86-4036, $117 \mathrm{p}$.

Van Metre, P.C., Mahler, B.J., and Furlong, E.T., 2000, Urban sprawl leaves its PAH signature: Environmental Science and Technology, v. 34, no. 19, p. $4,064-4,070$

Any use of trade, product, or firm names is for descriptive purposes only and does not imply endorsement by the U.S. Government.

Information on technical reports and hydrologic data related to this study can be obtained from:

District Chief

U.S. Geological Survey

8027 Exchange Dr.

Austin, TX 78754-4733

E-mail: dc_tx@usgs.gov
Phone: (512) 927-3500

FAX: (512) 927-3590

World Wide Web:

http://tx.usgs.gov/ 